\title{
Nafkah Sebuah Konsekuensi Logis dari Pernikahan
}

\author{
Isniyatin Faizah \\ Institut Agama Islam Nahdlatul Ulama Tuban \\ E-mail: isniyatinfaizah@gmail.com
}

\begin{abstract}
Abstrak: Pemberian nafkah merupakan kewajiban seorang suami terhadap isteri setelah adanya ikatan pernikahan yang sah, isteri menyerahkan dirinya kepada suaminya, isteri bersedia diajak pindah tempat sesuai dengan keinginan suami, isteri tersebut adalah orang yang telah dewasa, isteri patuh dan taat kepada suami. Dalam hal seperti ini isteri berhak mendapatkan apa yang menjadi haknya selama isteri tidak nusyuz dan tidak ada sebab lain yang akan menyebabkan terhalangnya nafkah, yang mengakui bahwa orang yang menjadi milik orang lain dan diambil manfaatnya maka nafkahnya menjadi tanggungan orang yang menguasainya. Adapun ukuran nafkah itu diukur berdasarkan kebutuhan isteri yang mencakup sandang, pangan dan papan, sedangkan ulama mazhab lain mengatakan disesuaikan kondisi suami, bukan kondisi isteri. Adapun nafkah bagi isteri ghaib ketika akad dilaksanakan dan suami mengetahui bahwa isterinya itu seorang wanita pekerja/karir yang tidak mungkin tinggal di rumah, maka suami tidak berhak meminta isterinya untuk meninggalkan pekerjaannya. Akan tetapi kalau suami memintanya juga, dan isterinya tidak memenuhi permintaannya tersebut, maka kewajiban memberi nafkah kepada isterinya itu tidak menjadi gugur. Apabila suami tidak mengetahui kalau isterinya adalah seorang wanita pekerja/karir ketika akad dilaksanakan, maka suami berhak meminta isterinya meninggalkan pekerjaannya, dan kalau isterinya tidak memenuhi permintaannya tersebut, maka dia tidak berhak atas nafkah.
\end{abstract}

Kata kunci: Pernikahan, hak isteri, nafkah.

\section{Pendahuluan}

Pernikahan merupakan ikatan lahir batin yang terbentuk antara seorang pria dengan seorang wanita sebagai sepasang suami isteri. Pernikahan dapat dikatakan sebagai sebuah ikatan suci bagi kedua manusia untuk dapat berhubungan secara sah. Kompilasi Hukum Islam juga menjelaskan bahwa pernikahan adalah akad yang sangat kuat untuk mentaati perintah Allah dan yang melaksanakan merupakan ibadah. Berlangsungnya sebuah akad antara sepasang suami isteri bukan hanya 
sekedar mengesahkan hubungan antara dua manusia yang saling mencintai, akan tetapi menimbulkan adanya hak dan kewajiban antara suami dan isteri dalam pengurusan rumah tangga.

Di antara kewajiban suami terhadap isteri yang paling pokok adalah kewajiban memberi nafkah, baik berupa makanan, pakaian, maupun tempat tinggal bersama sebagai bentuk konsekuensi dari pernikahan. Islam juga mewajibkan suami berusaha mencari nafkah untuk memenuhi kebutuhan hidup isteri dan anak-anaknya. Islam menekankan kaum lakilaki untuk memberikan nafkah kepada isteri mengandung hikmah yang mulia yakni mengangkat martabat wanita agar tidak terlalu bekerja keras mencari nafkah untuk kepentingan rumah tangganya, dalam hal ini bukan berarti wanita tidak diperbolehkan mencari nafkah. Seorang wanita juga mempunyai hak untuk mencari nafkah dengan syarat memperoleh izin dari suami atau pada suatu waktu sang suami tidak sanggup lagi bekerja karena sakit atau sebab lain, barulah isteri yang turun tangan untuk membantu suaminya dalam menanggulangi urusan rumah tangga.

Pada dasarnya setiap orang yang menahan hak orang lain untuk kemanfaatannya sendiri, maka ia harus bertanggung jawab untuk membelanjainya. Hal ini sudah merupakan kaidah umum. Berdasarkan kaidah tersebut, Islam mewajibkan kepada suami untuk memberikan nafkah kepada seorang isteri. Adanya ikatan pernikahan yang sah menjadikan seorang isteri terikat. Isteri wajib taat kepada suami, tinggal dirumahnya, mengurus rumah tangganya, serta memelihara dan mendidik anak-anaknya. Sebaliknya suami bertanggung jawab untuk memenuhi kebutuhan isteri. Memberi belanja kepada isteri selama ikatan sebagai suami isteri masih terjalin dan isteri tidak durhaka, atau hal-hal lain yang menghalangi pemberian nafkah.

\section{Pengertian Nafkah}

Nafkah berasal dari bahasa Arab yaitu al-nafaqah: al-mashrufu wa alinfaqu (النفقة: المصروف والإنفاق) artinya biaya, belanja1. Nafkah menurut bahasa adalah الإخراج و الذهاب (mengeluarkan harta benda). Sedangkan menurut istilah adalah pemenuhan kebutuhan isteri berupa makanan,

\footnotetext{
${ }^{1}$ Ahmad Warson Munawwir, Kamus al-Munawwir Arab-Indonesia Terlengkap (Surabaya: Pustaka Progressif, 1997), hlm. 1449

2 Abdur Rahman al-Jaziri, Kitab al-Fiqih ala al-Madzahib al-Arba'ah: Qism al-Ahwal alSyakhshiyyah (Bairut Libanon: Dar al-Fikr, 2002), hlm. 426
} 
tempat tinggal, pelayanan, dan pengobatan meskipun isteri berkecukupan. ${ }^{3}$

Nafkah menurut para fuqaha adalah":

النفقة هي إخر اج الثخص مؤونة من تجب عليه نفقته من خبز, وأدم, وكسوة, ومسكن, وما يتبع ذلك من ثمن ماء, ودهن, ومصباح, ونحو ذلك.

Artinya nafkah adalah seseorang mengeluarkan ongkos/biaya terhadap orang yang wajib dinafkahinya dari roti, lauk-pauk, pakaian, tempat tinggal dan apa yang bersangkutan seperti dari harga air, lampu, minyak dan sebagainya.

Nafkah menurut para ulama adalah belanja untuk keperluan makan yang mencakup sembilan bahan pokok, pakaian dan perumahan (sandang, pangan dan papan). Selain dari tiga pokok tersebut para ulama berbeda pendapat. 5

Dari beberapa definisi di atas dapat ditarik kesimpulan bahwa yang dimaksud dengan nafkah adalah semua biaya perbelanjaan atau pengeluaran seseorang untuk mencukupi dan memenuhi kebutuhan pokok yang dibutuhkan, adapun kebutuhan pokok yang dimaksud di atas pada dasarnya dapat digolongkan dalam tiga macam, yaitu sandang, pangan dan papan.

\section{Dasar Hukum Nafkah}

Dalil wajib memberi nafkah terdapat dalam surat al-Baqarah ayat 233.

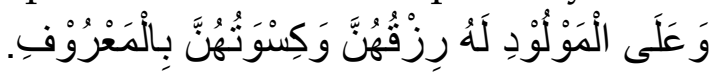

Artinya: "Dan kewajiban ayah menanggung nafkah dan pakaian mereka dengan cara yang patut. (QS. al-Baqarah: 233). ${ }^{6}$

Maksudnya adalah ayah bagi anak yang dilahirkan. Pemberian nafkah dalam ketentuan ini berupa makanan secukupnya. Pakaian adalah busana penutup aurat. Ma'ruf adalah ketentuan yang berlaku dan diketahui secara umum dalam tradisi yang tidak bertentangan dengan syari'at tanpa berlebihan, tidak pula kurang. ${ }^{7}$

Surat at-Thalaq ayat 6-7.

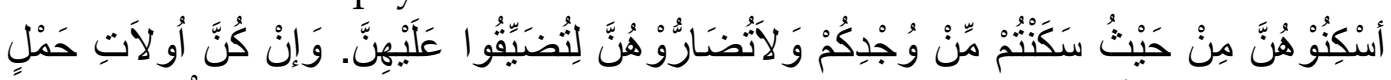

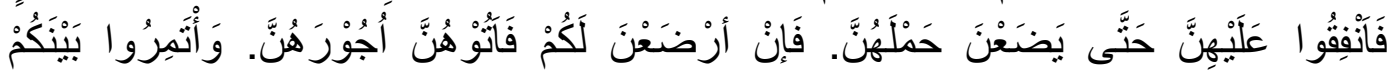

\footnotetext{
${ }^{3}$ Sayyid Sabiq, Fikih Sunnah, Terj. Muhammad Nasiruddin al-Albani (Jakarta: Cakrawala, 2011), hlm. 427

${ }^{4}$ Abdur Rahman al-Jaziri, hlm. 426

${ }^{5}$ Amir Syarifuddin, Hukum Perkawinan Islam di Indonesia (Jakarta: Prenada Media, 2007), hlm. 166

${ }^{6}$ Q.S. al-Baqarah:233

7 Sayyid Sabiq, hlm. 427
} 


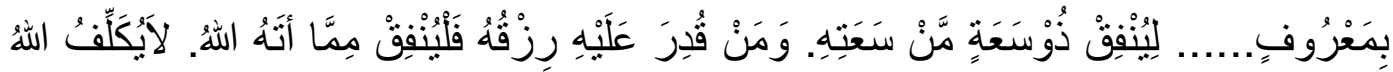

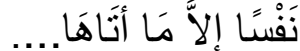

Artinya: "Tempatkanlah mereka (para isteri) di mana kamu bertempat tinggal menurut kemampuanmu dan janganlah kamu menyusahkan mereka untuk menyempitkan (hati) mereka. Dan jika mereka (isteri-isteri yang sudah di talak) itu sedang hamil, maka berikanlah kepada mereka nafkahnya sampai mereka melahirkan kandungannya. Kemudian jika mereka menyusukan (anak-anak)-mu maka berikanlah imbalannya kepada mereka(6). Hendaklah orang yang mempunyai keluasan memberi nafkah menurut kemampuannya, dan orang yang terbatas rezekinya, hendaklah memberi nafkah dari harta yang diberikan Allah kepadanya. Allah tidak membebani seseorang melainkan (sesuai) dengan apa yang diberikan Allah kepadanya(7). (QS. al-Thalaq 6-7). ${ }^{8}$

Landasan wajib memberi nafkah yang bersumber dari Hadis Nabi Muhammad adalah:

Muslim meriwayatkan, Rasulullah saw bersabda pada saat Hajjatul wada'.9

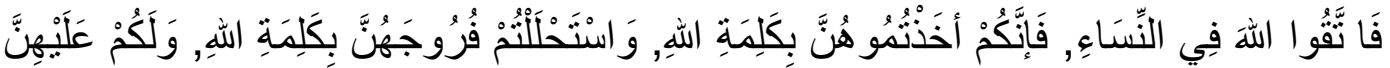

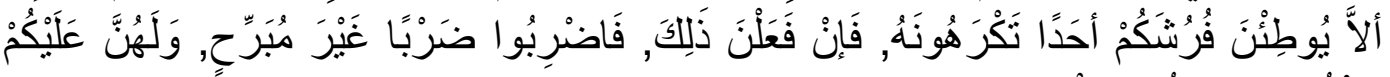

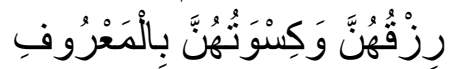

Artinya: "Takutlah kepada Allah terkait kaum perempuan. Sesungguhnya kalian telah mengambil mereka dengan kalimat (ikatan perjanjian) Allah dan kemaluan mereka dihalalkan bagi kalian dengan kalimat Allah. Hak kalian yang harus mereka penuhi adalah mereka tidak boleh mempersilahkan seorang pun yang tidak kalian sukai berada diranjang kalian. Jika mereka melakukan itu, maka pukullah mereka dengan pukulan yang tidak keras (sebagai pelajaran). Dan hak mereka yang harus kalian penuhi adalah memberi mereka makan dan pakaian dengan selayaknya. (HR. Muslim).

Hakim bin Muawiyah al-Qusyairy ra. berkata: aku bertanya kepada Rasulullah saw., wahai Rasulullah, apa hak isteri salah seorang di antara kami yang harus dipenuhinya? Beliau menjawab. ${ }^{10}$

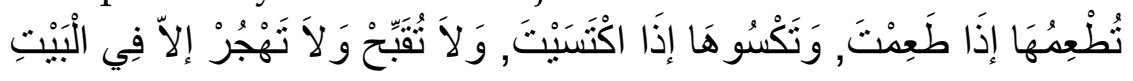

\footnotetext{
${ }^{8}$ Q.S. al-Thalāq: 6-7

${ }^{9}$ Syaikh Mahmud al-Mashri, Perkawinan Idaman (Jakarta: Qisti Press, 2010), hlm. 122

10 HR. Abu Daud, Kitab "an-Nikah", bab fi Haqq al-Mar'ah ala Zaujiha", hlm. 606. Lihat dalam Sayyid Sabiq, Fikih Sunnah, Terj. Muhammad Nasiruddin al-Albani (Jakarta: Cakrawala, 2011), hlm. 429
} 
Artinya: "Hendaknya kamu memberinya makan jika kamu makan, dan memberinya pakaian jika kamu mengenakan pakaian, dan jangan memukul wajah, jangan menjelek-jelekkan, serta jangan berseteru kecuali di dalam rumah.

Landasan atas wajibnya memberi nafkah sesuai dengan ijma' ulama adalah Ibnu Qudamah berkata: para ulama sepakat bahwa memberi nafkah kepada isteri merupakan kewajiban yang harus dipenuhi suami jika suami sudah berusia baligh kecuali terhadap isteri yang membangkang. Hal ini juga disampaikan oleh Ibnu Mundzir dan yang lain. Dia berkata, bahwasanya perempuan tertahan pada suami yang membuatnya tidak dapat beraktivitas dengan leluasa dan mencari penghasilan, maka suami harus memenuhi kebutuhannya dengan memberikan nafkah. ${ }^{11}$

\section{Orang yang Berhak Menerima Nafkah}

Orang yang berhak menerima nafkah yaitu istri, anak, pembantu dan kaum kerabat yang tidak mampu. ${ }^{12}$ Namun para ulama berbeda pendapat tentang urutan kaum kerabat yang wajib di beri nafkah.

Menurut Hanafi, kalau orang yang wajib memberi nafkah itu hanya seorang, maka kewajiban itu harus dilaksanakannya sendiri. Sedangkan apabila jumlah mereka berbilang, sedangkan mereka itu berada dalam peringkat yang sama dan dalam tingkat kemampuan yang sama, misalnya dua orang anak laki-laki atau dua orang anak perempuan, maka pemberian nafkah tersebut diwajibkan atas mereka sama rata, sekalipun kekayaan mereka itu terbukti berbeda.

Menurut Syafi'i, kalau seseorang membutuhkan nafkah, dan dia mempunyai ayah dan kakek yang kaya, maka kewajiban memberi nafkah hanya dibebankan kepada ayah saja, dan apabila dia mempunyai ibu dan nenek dari pihak ibu, maka nafkah tersebut merupakan kewajiban ibu. Kalau dia mempunyai ayah dan ibu, maka kewajiban tersebut berada di pundak ayah, dan apabila dia mempunyai kakek dan ibu, maka kewajiban tersebut berada ditangan kakek. Tetapi kalau dia mempunyai kedua nenek dari pihak ayah dan ibu, maka kewajiban itu dibagi rata dan ada yang berpendapat kewajiban itu hanya pada nenek dari pihak ayah.

Menurut Hanbali, apabila seorang anak kecil tidak mempunyai ayah, maka nafkahnya merupakan kewajiban orang-orang yang menjadi

11 Sayyid Sabiq, hlm. 429

12 Sayyid Sabiq, hlm. 550 
pewarisnya. Kalau dia mempunyai dua orang atau lebih yang merupakan pewaris, maka kewajiban nafkah itu berada di pundak mereka berdua sesuai dengan ketentuan hak waris mereka. Kalau dia mempunyai seorang ibu dan kakek, maka kewajiban ibu untuk memberi nafkah adalah sepertiga (dari seluruh kebutuhan nafkah), sedangkan selebihnya ditanggung oleh kakek.13

\section{Sebab-sebab Wajib Memberi Nafkah}

Sebab-sebab yang mewajibkan nafkah terbagi menjadi tiga, yaitu ${ }^{14}$ :

1. Sebab pernikahan, diwajibkan atas suami memberi belanja kepada isterinya yang taat, baik makanan atau pakaian, maupun tempat tinggal dan perkakas rumah tangga menurut keadaan di tempat masing-masing dan tingkatan suami. Sebagaimana firman Allah surat an-Nisa ayat 34.

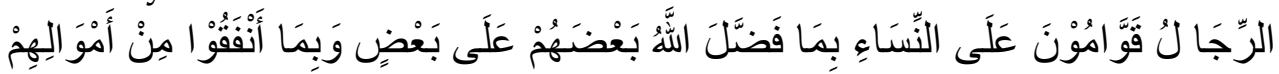

Artinya: "Laki-laki (suami) itu pelindung bagi perempuan (isteri), karena Allah telah melebihkan sebagia mereka (laki-laki) atas sebagian yang lain (perempuan), dan karena mereka (laki-laki) telah memberikan nafkah dan hartanya. ${ }^{15}$

Terdapat dua alasan yang dikemukakan dalam ayat diatas: pertama, karena Allah melebihkan sebagian mereka atas sebagian yang lain. Kedua, karena mereka (para suami) untuk menafkahkan sebagian dari harta mereka (untuk isteri/keluarganya) ${ }^{16}$.

2. Sebab keluarga atau turunan, wajib atas bapak atau ibu kalau bapak tidak ada, memberi belanja kepada anaknya, begitu juga kepada cucu kalau dia tidak mempunyai bapak. Sebagaimana sabda Rasulullah saw.

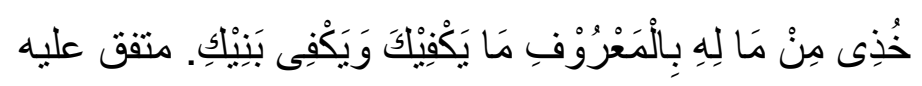

Isteri Abu Sofyan, telah mengadukan halnya kepada Rasulullah saw, dia berkata: Abu Sofyan seorang yang kikir, dia tidak memberi saya dan anak saya belanja selain daripada yang saya ambil dengan tidak diketahuinya, adakah yang demikian memudaratkan kepada saya? Jawab beliau: "ambil olehmu dari hartanya dengan baik, sekadar yang mencukupi keperluanmu dan anakmu".

\footnotetext{
${ }^{13}$ Muhammad Jawad Mughniyah, hlm. 437

14 Abdur Rahman al-Jaziri, Kitab al-Fiqih ala al-Madzahib al-Arba'ah: Qism al-Ahwal alSyakhshiyyah (Bairut Libanon: Dar al-Fikr, 2002), hlm. 426. Lihat juga dalam Sulaiman Rasjid, Fiqih Islam (Jakarta: Attahiriyah, 1976), hlm. 399-400.

${ }^{15}$ Q.S. al-Nisā': 34

${ }^{16}$ M. Quraisy Shihab, Wawasan al-Qur'an (Bandung: Mizan, 2003), hlm. 210
} 
Ketentuan nafkah bagi kaum kerabat, menurut Abu Hanifah nafkah wajib bagi kaum kerabat ketika hubungan kekerabatan antara mereka merupakan hubungan yang menyebabkan keharaman nikah di antara mereka. Dengan demikian, kewajiban nafkah-menafkahi itu mencakup para ayah hingga ke atas, para anak hingga ke bawah. Juga mencakup saudara laki-laki dan perempuan, paman dan bibi dari pihak ayah, serta paman dan bibi dari pihak ibu, sebab mereka semua terlarang nikah satu sama lain. ${ }^{17}$

Menurut Maliki, nafkah hanya wajib bagi dua orang tua dan anak-anak yang merupakan keturunan langsung, dan tidak mencakup orang-orang lain yang berada pada jalur keturunan pokok maupun cabang. Menurut Hambali, para ayah dan seterusnya ke atas wajib memberi dan berhak atas nafkah, begitu juga dengan para anak dan terus ke bawah, baik mereka berhak atas waris atau tidak.

Menurut Syafi'i, para anak wajib memberi nafkah kepada orang tua mereka dan seterusnya ke atas, baik mereka itu laki-laki maupun perempuan, seperti halnya dengan orang tua yang berkewajiban memberi nafkah kepada anak-anaknya, baik mereka itu laki-laki maupun perempuan. Kewajiban memberi nafkah tidak mencakup orang-orang yang berada di luar jalur nasab.

Syarat-syarat kewajiban memberi nafkah kepada kerabat adalah sebagai berikut:

a. Adanya hubungan kerabat yang mewajibkan adanya hubungan waris-mewaris antara kerabat yang membutuhkan dan kerabat yang mampu. ${ }^{18}$

b. Adanya kebutuhan kerabat yang menuntut nafkah.

c. Orang yang dibebani kewajiban nafkah cukup mampu.

d. Harus seagama, kalau salah seorang di antaranya muslim dan yang lainnya non-muslim, maka menurut Hambali tidak ada kewajiban memberikan nafkah. Menurut Maliki dan Syafi'i, tidak disyaratkan harus seagama. Menurut Hanafi, dalam kaitannya dengan ayah dan anak, tidak di syaratkan harus seagama, sedangkan bila bukan ayah dan anak diharuskan seagama. ${ }^{19}$

\footnotetext{
${ }^{17}$ Muhammad Jawad Mughniyah, hlm. 430-432

${ }^{18}$ M. A. Tihami dan Sohari Sahrani, Fikih Munakahat: Kajian Fikih Nikah Lengkap (Jakarta: Rajawali Pers, 2010), hlm. 168

${ }^{19}$ Muhammad Jawad Mughniyah, hlm. 434
} 
3. Sebab milik, binatang yang dimiliki oleh seseorang wajib atasnya memberi makan binatang itu, dan dia wajib menjaganya jangan sampai diberi beban lebih dari mestinya. Sebagaimana sabda Rasulullah saw.

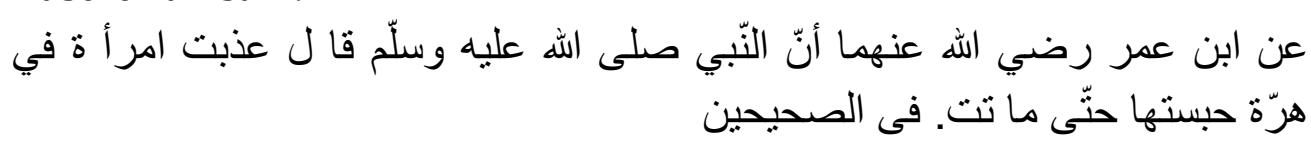

Artinya: Dari Ibnu Umar, bahwasanya Nabi Muhammad saw telah berkata: "Telah disiksa seorang perempuan lantaran dia memenjarakan seekor kucing, tidak diberinya makan dan tidak pula diberinya minum, sehingga mati kucing itu". HR. Bukhori Muslim

\section{Sebab Isteri Mendapatkan Nafkah}

Nafkah adalah pemberian dari suami yang diberikan kepada isteri setelah adanya suatu akad pernikahan. Nafkah wajib karena adanya akad yang sah, penyerahan diri isteri kepada suami, dan memungkinkan untuk terjadinya bersenang-senang. Syari'at mewajibkan nafkah atas suami kepada isterinya. Nafkah hanya diwajibkan atas suami karena tuntutan akad nikah dan karena keberlangsungan bersenang-senang sebagaimana isteri wajib taat kepada suami, selalu menyertainya, mengatur rumah tangga, mendidik anak-anaknya. Ia tertahan untuk melaksanakan haknya, "setiap orang yang tertahan untuk hak orang lain dan manfaatnya, maka nafkahnya atas orang yang menahan karenanya". ${ }^{20}$

Jadi yang menyebabkan seorang isteri mendapatkan nafkah dari suami adalah selama pernikahan berlangsung dan selama isteri tidak nusyuz dan tidak ada sebab lain yang akan menyebabkan terhalangnya nafkah berdasarkan kaidah umum, yang mengakui bahwa orang yang menjadi milik orang lain dan diambil manfaatnya maka nafkahnya menjadi tanggungan orang yang menguasainya. ${ }^{21}$

Di dalam Pasal $80(1,2,3,4)$ Kompilasi mengatur kewajiban suami terhadap isteri dan keluarganya, yang berbunyi:22

a. Suami adalah pembimbing terhadap Isteri dan rumah tangganya akan tetapi mengenai hal-hal rumah tangganya yang penting-penting diputuskan oleh suami isteri bersama.

\footnotetext{
${ }^{20}$ Abdul Aziz Muhammad Azzam, Fiqh Munakahat (Jakarta : Amzah, 2009), hlm. 212-213

${ }^{21}$ Sa'id Thalib Hamdani, Risalah al-Nikah (Jakarta: Pustaka Amani, 1989), hlm. 124

22 Tim Redaksi Nuansa Aulia, Kompilasi Hukum Islam (Bandung : CV. Nuansa Aulia, 2009), hlm. 26
} 
b. Suami wajib melindungi isterinya dan memberikan segala sesuatu keperluan hidup berumah tangga sesuai dengan kemampuannya.

c. Suami wajib memberi pendidikan agama kepada isterinya dan memberi kesempatan belajar pengetahuan yang berguna dan bermanfaat bagi agama, nusa dan bangsa.

d. Sesuai dengan penghasilannya suami menanggung :

1. Nafkah, kiswah, dan tempat kediaman bagi isteri.

2. Biaya rumah tangga, perawatan, dan pengobatan bagi isteri dan anak.

3. Biaya pendidikan anak

\section{Syarat Isteri Mendapatkan Nafkah}

Ulama telah sepakat bahwa hak isteri terhadap suaminya adalah mendapatkan nafkah. ${ }^{23}$ Nafkah tersebut akan diperoleh oleh seorang isteri jika telah terpenuhi persyaratan berikut ini:

1. Antara isteri dan suami yang memberikan nafkah telah terjadi akad nikah yang sah. ${ }^{24}$ Dengan kata lain pernikahan itu memenuhi rukun dan syarat, apabila perkawinan mereka termasuk nikah fasid (rusak/batal) maka menurut jumhur ulama tidak wajib nafkah karena nikah fasid harus dibatalkan. ${ }^{25}$

2. Isteri bersedia menyerahkan dirinya kepada suaminya. Ketika isteri sudah berikrar menyerahkan dirinya kepada sang suami maka pada saat itu juga sang isteri sudah berhak mendapatkan nafkah dari suami walaupun saat itu belum melakukan hubungan suami isteri (jima'). ${ }^{26}$

3. Isteri bersedia diajak pindah tempat sesuai dengan keinginan suami. ${ }^{27}$ Seorang suami berhak menawarkan kepada isterinya untuk pindah pada tempat yang ditentukan olehnya. Apabila isteri menaati ajakan itu maka isteri berhak untuk mendapatkan nafkah dari suaminya namun jika menolak dengan alasan yang tidak dapat dibenarkan secara syar'i atauisteri bepergian tanpa izin suami maka hak nafkah menjadi hilang. ${ }^{28}$

\footnotetext{
${ }^{23}$ Ibnu Rusyd al-Hafid, Bidayat al-Mujtahid wa Nihayat al-Muqtashid. Terj. Imam Ghazali Sa'id dan Ahmad Zaidun (Jakarta: Pustaka Amani, 2007), hlm. 518

${ }^{24}$ Sayyid Sabiq, hlm. 430

${ }^{25}$ Abdul Azis Dahlan, Ensiklopedi Hukum Islam (Jakarta: PT Intermasa, 2001), hlm. 1282

${ }^{26}$ Abdul Azis Dahlan, hlm. 1282

27 Sayyid Sabiq, hlm. 430

${ }^{28}$ Syaikh Hasan Ayyub, hlm. 386
} 
4. Isteri tersebut adalah orang yang telah dewasa, dalam arti telah layak melakukan hubungan senggama. Apabila isteri itu masih kecil sehingga belum layak untuk disenggamai, maka tidak ada nafkah baginya karena kewajiban nafkah itu muncul dari dimungkinkannya melakukan hubungan suami isteri. ${ }^{29}$ Misalnya Rasulullah saw. yang ketika itu menikahi Aisyah yang masih berusia muda, Rasulullah tidak memberi nafkah karena belum pernah disenggamai. Setelah Aisyah siap disenggamai (dewasa) maka saat itu pula Rasulullah berkewajiban untuk menafkahinya.

5. Isteri taat dan patuh pada suaminya. Apabila isteri itu tidak patuh dan taat seperti isteri yang nusyuz, maka suami tidak wajib membayar nafkahnya. ${ }^{30}$ Apabila nusyuz itu munculnya dari suami, maka isteri tetap berhak mendapatkan nafkah dari suaminya itu.

\section{Ukuran Nafkah}

Para ulama mazhab sepakat bahwa besar kecilnya nafkah tergantung pada keadaan kedua belah pihak. Kalau suami isteri orang berada, maka nafkah yang wajib diberikan adalah nafkah orang yang berada, kalau mereka tidak mampu, maka nafkahnya disesuaikan. Adapun maksud dari kadar "berada" dan "tidak berada"-nya isteri adalah kadar berada dan tidak beradanya keluarganya, yakni kadar kehidupan keluarganya. ${ }^{31}$

Mereka berbeda pendapat apabila seorang di antara suami-isteri itu kaya, sedangkan yang satu lagi miskin. Dalam keadaan seperti itu, apakah nafkah tersebut diukur berdasar kondisi suami saja, misalnya bila dia kaya, maka nafkahnya juga besar, sekalipun isterinya miskin, atau sebaliknya, ataukah diperhitungkan berdasar kondisi mereka berdua.

Menurut Maliki dan Hambali bahwa besarnya nafkah itu tidak ditentukan berdasarkan ketentuan syara', tetapi berdasarkan keadaan masing-masing suami-isteri, dan ini akan berbeda-beda berdasarkan perbedaan tempat, waktu dan keadaan. ${ }^{32}$

Menurut Syafi'i bahwa batas minimal nafkah yang harus diberikan suami kepada isterinya adalah apa yang biasa berlaku di negeri keduanya. Apabila yang biasa berlaku bahwa umumnya perempuan seperti dirinya mesti memiliki pembantu, maka hendaknya suami mengusahakan

${ }^{29}$ Imam Syafi'i, Mukhtashar Kitab al-Umm fii al-Fiqh, terj. Abu Vida' Anshari (Kudus: MenaraKudus, 2006), hlm. 108-109

${ }^{30}$ Ibnu Rusyd al-Hafid, hlm. 520

${ }^{31}$ Muhammad Jawad Mughniyah, hlm. 422

32 Ibnu Rusyd al-Hafid., hlm. 519 
pembantu bagi isterinya, paling sedikit satu orang. Sedangkan batas minimal nafkah yang harus diberikan suami kepada isterinya adalah sebanyak dimana badan seseorang tidak dapat tegak bila diberi makan kurang dari itu, jumlah tersebut adalah mud (enam ons) setiap hari dengan standar mud Nabi saw yang terdiri dari makanan pokok negeri dimana suami isteri itu berada, sehingga dalam sebulan seluruhnya berjumlah 30 $m u d$, dan bagi pembantu isterinya serupa dengan itu. ${ }^{33}$

Jadi menurut Syafi'i bahwa nafkah itu ditentukan besarnya. Bagi orang kaya dua mud. Orang yang sedang satu setengah mud, dan orang yang miskin satu mud. ${ }^{34}$ Menurut Abu Hanifah bahwa nafkah bagi orang yang berada dalam kemudahan, maka ia harus memberikan tujuh sampai delapan dirham dalam satu bulannya dan bagi yang berada dalam kesulitan memberikan empat sampai lima dirham pada setiap bulannya. ${ }^{35}$

Sementara itu, mayoritas ulama mazhab Imamiyah berpendapat bahwa nafkah itu diukur berdasarkan kebutuhan isteri yang mencakup pangan, lauk-pauk, pakaian, tempat tinggal, pelayan, alat rumah tangga, sesuai dengan tingkat kehidupan orang-orang seperti dia di daerahnya. Sedangkan ulama mazhab lain mengatakan bahwa yang dijadikan ukuran adalah kondisi suami, bukan kondisi isteri. ${ }^{36}$

\section{Nafkah Isteri yang Ber'iddah}

Para ulama mazhab sepakat tentang wajibnya pemberian nafkah kepada isteri dengan syarat-syarat tertentu dan juga nafkah untuk wanita yang ditalak raj'i, serta tentang tidak adanya hak nafkah atas wanita yang menjalani iddah karena ditinggal mati suaminya, baik dalam keadaan mengandung atau tidak. Hanya saja Maliki dan Syafi'i berpendapat bahwa, wanita yang ditinggal mati suaminya berhak memperoleh nafkah berupa tempat tinggal. Selanjutnya imam Syafi'i mengatakan bahwa apabila seorang wanita ditalak ba'in, sedang dia dalam keadaan hamil kemudian suaminya meninggal dunia (ketika si isteri masih dalam keadaan iddah) maka nafkah atas si isteri tidak terputus.

Imam Hanafi mengatakan apabila wanita yang ber'iddah tersebut dalam keadaan talak raj'i dan suami menceraikannya itu meninggal dunia ketika dia menjalani iddahnya, maka iddahnya beralih ke iddah wafat,

\footnotetext{
${ }^{33}$ Imam Syafi'i, hlm. 107

${ }^{34}$ Ibnu Rusyd al-Hafid, hlm. 519

35 Syaikh Hasan Ayyub, hlm. 384

${ }^{36}$ Muhammad Jawad Mughniyah, hlm. 423
} 
dan kewajiban atas nafkah menjadi terputus, kecuali apabila si wanita itu diminta untuk menjadikan nafkahnya sebagai hutang (atas suami) yang betul-betul dilaksanakannya. Dalam kondisi serupa ini nafkahnya tidak gugur.

Selanjutnya para ulama mazhab sepakat bahwa wanita yang menjalani iddah karena percampuran syubhat, tidak berhak atas nafkah. Namun mereka berbeda pendapat tentang nafkah bagi wanita yang menjalani iddah karena talak ba'in. Imam Hanafi mengatakan, wanita tersebut berhak atas nafkah, sekalipun dia ditalak tiga, baik dia hamil atau tidak dengan syarat dia tidak meninggalkan rumah yang disediakan oleh suami yang menceraikannya guna menjalani iddah. Hukum wanita beriddah akibat fasakhnya akad menurut Hanafi sama dengan wanita yang ditalak ba'in. Sedangkan Maliki berpendapat kalau wanita tersebut tidak hamil, dia hanya berhak atas nafkah berupa tempat tinggal, akan tetapi apabila sedang hamil dia berhak atas nafkah dalam segala bentuknya. Haknya atas nafkah tidak menjadi gugur dengan keluarnya dia dari rumah iddah. Sebab nafkah tersebut diperuntukkan bagi bayi yang yang dikandung dan bukan untuk wanita yang mengandungnya.

Syafi'i, Imamiyah dan Hanbali mengatakan wanita tersebut tidak berhak atas nafkah apabila tidak mengandung, tetapi berhak atasnya apabila dia memang hamil. Akan tetapi Syafi'i mengatakan bahwa kalau wanita tersebut keluar dari rumah tanpa adanya kebutuhan, maka gugurlah hak atas nafkah. Mazhab Imamiyah tidak mengkategorikan fasakhnya akad yang sah sama dengan talak ba'in. Mereka berpendapat bahwa orang yang menjalani iddah akibat fasakhnya akad, baik dia hamil atau tidak, tidak berhak atas nafkah. ${ }^{37}$

Sayyid Sabiq mengatakan bahwasannya, wajib menafkahi wanita hamil, baik dalam iddah raj'i ataupun iddah wafat. ${ }^{38}$ Beliau mengacu pada al-Qur'an yang berbunyi:

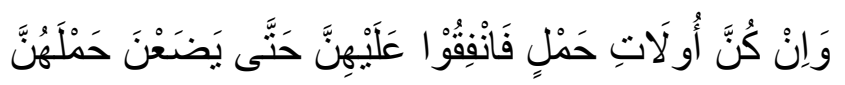

Artinya: “Apabila mereka hamil, maka nafkahilah mereka, sehingga mereka melahirkan kehamilan mereka itu. (QS. al-Thalaq: 6) Nafkah pada saat Suami Bepergian serta Nafkah Isteri Ghaib/Karir

Kewajiban seorang suami menafkahi isteri bukanlah didasarkan pada tradisi, budaya, adat istiadat masyarakat, atau warisan kebudayaan. Islam

37 Muhammad Jawad Mughniyah, hlm. 401-402

38 Sayyid Sabiq, hlm. 113 
menetapkan kewajiban memberikan nafkah kepada isteri sebagai suatu perintah Allah kepada hamba-Nya. Oleh karena itu, seorang suami yang tidak menunaikan kewajiban memberi nafkah kepada isterinya telah berdosa kepada isteri dan berdosa kepada Allah. ${ }^{39}$

Dalam undang-undang nomor 25 tahun 1920 butir 5 dinyatakan: jika suami bepergian ke tempat yang dekat, jika dia memiliki harta yang tampak, maka ditetapkan baginya secara hukum bahwa harta itu boleh diberikan sebagai nafkah. Jika dia tidak memiliki harta yang tampak, maka hakim memakluminya dengan cara-cara yang wajar, dan dia diberi tanggungan waktu tertentu. Jika dia tidak mengirim nafkah untuk isteri yang ditanggungnya, maka hakim dapat menjatuhkan talak terhadapnya setelah batas waktu yang ditetapkan habis. Jika dia bepergian ke tempat yang jauh dan tidak mudah untuk dijangkau, lantaran keberadaannya tidak diketahui atau dia hilang dan dinyatakan bahwa dia tidak memiliki harta untuk dinafkahkan kepada isteri, maka hakim dapat menjatuhkan talak terhadapnya. ${ }^{40}$

Ulama mazhab berbeda pendapat dalam masalah adanya seorang penjamin nafkah ketika suami bermaksud bepergian jauh, sedangkan si isteri tidak ikut serta dan si suami tidak meninggalkan sesuatu untuknya. Menurut Abu Hanifah, Maliki dan Hambali, si isteri berhak menuntut adanya penjamin nafkah, dan si suami harus menunjuk seorang penjamin nafkah. Kalau si suami tidak bersedia, maka si isteri berhak mencegahnya bepergian. Bahkan Maliki mengatakan si isteri berhak meminta kepada suaminya untuk membayar lebih dulu nafkahnya (untuk masa yang akan datang) manakala si suami menyatakan bahwa dia bermaksud bepergian seperti biasanya. ${ }^{41}$

Menurut syafi' $i$, isteri tidak berhak meminta penjamin bagi nafkahnya untuk waktu-waktu yang akan datang, sebab belum pasti bahwa itu merupakan tanggungan suami, dan bahwasannya nafkah sewaktu-waktu bisa gugur bila terjadi nusyuz, talak dan kematian. Adapun nafkah bagi wanita yang bekerja, imam Abu Hanifah menegaskan bahwa, manakala isteri adalah seorang wanita pekerja dan tidak menetap di rumah, maka dia tidak berhak atas nafkah manakala suaminya memintanya tetap

\footnotetext{
${ }^{39}$ M. Thalib, Ketentuan Nafkah Isteri dan Anak (Bandung: Irsyad Baitus Salam, 2000), hlm. 22-23

40 Sayyid Sabiq, hlm. 428

${ }^{41}$ Muhammad Jawad Mughniyah, hlm. 427
} 
tinggal di rumah tetapi si isteri menolak. Bahkan imam Syafi'i dan imam Hambali lebih menegaskan lagi dengan mengatakan bahwa, kalau isteri keluar rumah dengan izin suami tapi demi kepentingannya sendiri, maka gugurlah hak nafkah untuknya.

Menurut pendapat yang lain, ketika akad dilaksanakan dan suami mengetahui bahwa isterinya itu seorang wanita pekerja yang tidak mungkin tinggal di rumah. Apabila si suami diam saja dan tidak mensyaratkan agar si isterinya meninggalkan pekerjaannya, maka dia tidak berhak meminta isterinya untuk meninggalkan pekerjaannya. Akan tetapi kalau si suami memintanya juga, dan si isterinya tidak memenuhi permintaannya tersebut, maka kewajiban memberi nafkah kepada isterinya itu tidak menjadi gugur. ${ }^{42}$ Apabila si suami tidak mengetahui kalau isterinya adalah seorang wanita pekerja ketika akad dilaksanakan, maka si suami berhak meminta isterinya meninggalkan pekerjaannya, dan kalau si isterinya tidak memenuhi permintaannya tersebut, maka dia tidak berhak atas nafkah.

\section{Penutup}

Nafkah adalah semua biaya perbelanjaan atau pengeluaran seseorang untuk mencukupi dan memenuhi kebutuhan pokok yang dibutuhkan, adapun kebutuhan pokok yang dimaksud di atas pada dasarnya dapat digolongkan dalam tiga macam, yaitu sandang, pangan dan papan. Orang yang berhak menerima nafkah yaitu istri, anak dan kaum kerabat yang tidak mampu. Dasar hukum wajib nafkah terdapat dalam surat alBaqarah ayat 233 dan at-Thalaq ayat 6-7.

Sebab-sebab wajib memberi nafkah ada tiga, pertama sebab pernikahan, kedua sebab keluarga dan ketiga sebab milik. Sebab istri mendapatkan nafkah adalah selama pernikahan berlangsung dan selama istri tidak nusyuz dan tidak ada sebab lain yang akan menyebabkan terhalangnya nafkah berdasarkan kaidah umum. Syarat seorang istri mendapatkan nafkah adalah adanya akad nikah secara sah, istri menyerahkan dirinya kepada suaminya, Istri bersedia diajak pindah tempat sesuai dengan keinginan suami, Istri tersebut adalah orang yang telah dewasa, dan istri patuh dan taat kepada suami.

Ukuran nafkah itu diukur berdasarkan kebutuhan istri yang mencakup pangan, lauk-pauk, pakaian, tempat tinggal, pelayan, alat rumah tangga, sesuai dengan tingkat kehidupan orang-orang seperti dia

${ }^{42}$ Muhammad Jawad Mughniyah, hlm. 426 
di daerahnya. Sedangkan ulama mazhab lain mengatakan bahwa yang dijadikan ukuran adalah kondisi suami, bukan kondisi istri.

Nafkah bagi istri ghaib ketika akad dilaksanakan dan suami mengetahui bahwa istrinya itu seorang wanita pekerja yang tidak mungkin tinggal di rumah, maka si suami tidak berhak meminta istrinya untuk meninggalkan pekerjaannya. Akan tetapi kalau si suami memintanya juga, dan si istrinya tidak memenuhi permintaannya tersebut, maka kewajiban memberi nafkah kepada istrinya itu tidak menjadi gugur. Apabila si suami tidak mengetahui kalau istrinya adalah seorang wanita pekerja ketika akad dilaksanakan, maka si suami berhak meminta istrinya meninggalkan pekerjaannya, dan kalau si istrinya tidak memenuhi permintaannya tersebut, maka dia tidak berhak atas nafkah.

\section{Daftar Pustaka}

Abdul Azis Dahlan. Ensiklopedi Hukum Islam. Jakarta: PT Intermasa, 2001.

Abdur Rahman al-Jaziri. Kitab al-Fiqih ala al-Madzahib al-Arba'ah: Qism alAhwal al-Syakhshiyyah. Bairut Libanon: Dar al-Fikr, 2002.

Ahmad Warson Munawwir. Kamus al-Munawwir Arab-Indonesia Terlengkap. Surabaya: Pustaka Progressif, 1997.

Amir Syarifuddin. Hukum Perkawinan Islam di Indonesia. Jakarta: Prenada Media, 2007.

Aziz Muhammad Azzam, Abdul, Figh Munakahat. Jakarta : Amzah, 2009.

Ghazali Sa'id dan Ahmad Zaidun. Jakarta: Pustaka Amani, 2007.

Ibnu Rusyd al-Hafid. Bidayat al-Mujtahid wa Nihayat al-Muqtashid. Terj. Imam Ghazali Sa'id dan Ahmad Zaidun. Jakarta: Pustaka Amani, 2007.

Imam Syafi'i. Mukhtashar Kitab al-Umm fii al-Fiqh, terj. Abu Vida' Anshari. Kudus: MenaraKudus, 2006.

M. Thalib. Ketentuan Nafkah Isteri dan Anak. Bandung: Irsyad Baitus Salam, 2000.

M. Quraisy Shihab. Wawasan al-Qur'an. Bandung: Mizan, 2003.

Muhammad Jawad Mughniyah. Fiqih Lima Madzhab. Jakarta: Lentera, 2012.

Sa'id Thalib Hamdani. Risalah al-Nikah. Jakarta: Pustaka Amani, 1989. Syaikh Mahmud al-Mashri. Perkawinan Idaman. Jakarta: Qisti Press, 2010. Sayyid Sabiq. Fikih Sunnah, Terj. Muhammad Nasiruddin al-Albani. Jakarta: Cakrawala, 2011. 
The Indonesian Journal of Islamic Law and Civil Law

Vol. I, No. I, April, 2020, ISSN. xxx - xxx

Tihami dan Sohari Sahrani. Fikih Munakahat: Kajian Fikih Nikah Lengkap. Jakarta: Rajawali Pers, 2010.

Tim Redaksi Nuansa Aulia. Kompilasi Hukum Islam. Bandung : CV. Nuansa Aulia, 2009. 